\title{
PELANGGARAN PRINSIP KERJA SAMA DALAM ACARA TALK SHOW ROSI DI KOMPAS TV
}

\author{
Riezka Noor Amalia ${ }^{1}$, Retnowaty ${ }^{2}$, Nurliani Maulida ${ }^{3}$ \\ Universitas Balikpapan ${ }^{1}$, Universitas Balikpapan ${ }^{2}$, Universitas Balikpapan ${ }^{3}$ \\ pos-el: riskanurramaliaa@gmail.com¹, retnowaty@uniba-bpn.ac.id ${ }^{2}$, nurliani.maulida@uniba-bpn.ac.id ${ }^{3}$
}

\begin{abstract}
ABSTRAK
Acara talk show Rosi banyak terjadi pelanggaran prinsip kerja sama, hal itu disebabkan karena lawan tutur mempunyai maksud atau tujuan tertentu dari pelanggaran itu untuk mengutarakan maksudnya secara halus. Oleh sebab itu, penelitian ini bertujuan untuk mendeskripsikan bentukbentuk pelanggaran prinsip kerja sama dalam percakapan pada acara Rosi di Kompas TV. Penelitian ini merupakan penelitian kualitatif. Subjek penelitian ini adalah proses komunikasi yang terjadi antara pewawancara dan narasumber pada talk show Rosi di Kompas TV. Objek penelitian ini yaitu percakapan yang diidentifikasi mengandung pelanggaran prinsip kerja sama dalam talk show Rosi di Kompas TV. Teknik pengumpulan data dalam penelitian ini yaitu metode simak dengan menyimak rekaman video acara Rosi bulan Juni 2018 yang telah diunduh di youtube, kemudian mencatat percakapan yang dicurigai terjadi pelanggaran prinsip kerja sama dan dianalisis, setelah itu dimasukkan ke dalam kartu data. Hasil penelitian ini menunjukkan bahwa terdapat pelanggaran prinsip kerja sama dalam acara talk show Rosi di Kompas TV pada bulan Juni 2018 sebanyak 55 data. Pelanggaran yang terjadi pada satu maksim, yaitu (1) maksim kuantitas sebanyak 31 data, (2) maksim kualitas sebanyak 2 data, (3) maksim relevansi sebanyak 4 data, dan (4) maksim cara sebanyak 11 data. Pelanggaran yang terjadi lebih dari satu maksim, yaitu (1) maksim kuantitas dan cara sebanyak 2 data, (2) maksim kuantitas dan kualitas sebanyak 2 data, (3) maksim kualitas dan cara sebanyak 2 data, dan (4) maksim relevansi dan cara sebanyak 1 data.
\end{abstract}

Kata kunci: Pelanggaran, Prinsip Kerja Sama, Talk Show Rosi, Kompas TV

\begin{abstract}
The talk show program has many violations of the principle of cooperation, it is because the opponent has a specific purpose or purpose of the violation to express his intentions subtly. Therefore, this study aims to describe the forms of violations of the principle of cooperation in the conversation at the Rosi program on Kompas TV. This research is a qualitative research. The subject of this research is the communication process that occurs between interviewers and speakers on the Rosi talk show at Kompas $T V$. The object of this research is conversations identified as containing violations of the principle of cooperation in the Rosi talk show on Kompas TV. The data collection technique in this study is the listening method by listening to the video recording of the Rosi program in June 2018 which was downloaded on youtube, then recorded the conversation that was suspected of violating the principle of cooperation and analyzed, after that it was entered into the data card. The results of this study indicate that there is a violation of the principle of cooperation in the Rosi talk show at Kompas TV in June 2018 totaling 55 data. Violations that occur in one maxim, namely (1) quantity maxim as many as 31 data, (2) quality maxim as much as 2 data, (3) relevance maxim as much as 4 data, and (4) implementation maxim as many as 11 data. Violations that occur more than one maxim, namely (1) quantity and implementation maxim as many as 2 data, (2) the maxim of quantity and quality as much as 2 data, (3) the maxim of the quality and implementation of 2 data, and (4) the maxim of relevance and implementation 1 data.
\end{abstract}

\section{Keywords: Violation, Coopereative Principle, Rosi Talk Show, Kompas TV}




\section{PENDAHULUAN}

Bahasa memiliki peranan yang sangat penting bagi manusia, karena dengan adanya bahasa manusia dapat menyampaikan pesan atau gagasan yang dipikirkan kepada lawan tuturnya. Bahasa haruslah dapat dipahami antara penutur dan mitra lawan tutur, karena proses komunikasi dapat berjalan dengan baik apabila kedua belah pihak dapat mematuhi prinsip kerja sama saat berkomunikasi.

Sperber dan Wilson (Nadar, 2009, hal. 26) membahas bahwa masalah komunikasi antara peserta dan pertuturan tidak akan terlepas dari pertanyaan dan sekaligus permasalahan bagaimana sesungguhnya komunikasi itu dapat terlaksana. Komunikasi yang berhasil bukanlah pada saat lawan tutur mengetahui makna linguistik tuturan penutur, melainkan pada saat lawan tutur tersebut dapat menangkap maksud penutur yang sesungguhnya lewat tuturannya. Suatu interaksi peserta tutur akan bekerja sama agar jalannya pertuturan dapat berjalan lancar, dan masing-masing peserta tutur akan dapat memahami apa yang diinginkan lawan tuturnya melalui tuturan yang dibuatnya.

Grice (Djatmika, 2016, hal. 34) menjelaskan prinsip kerja sama terdiri dari empat maksim, yaitu (1) maksim kuantitas, memberikan informasi sesuai yang dibutuhkan; (2) maksim kualitas, mengatakan hal yang sebenarnya yang didasari bukti yang memadai; (3) maksim relevansi, menyampaikan informasi yang relevan; (4) maksim pelaksanaan/cara, mengharuskan berbicara secara langsung, tidak berlebihan, dan tidak kabur. Apabila aturan-aturan tersebut saat proses komunikasi terjadi antara penutur dalam tuturannya tidak memenuhi keempat maksim tersebut, maka dampak yang akan terjadi yaitu proses komunikasi antara penutur dan lawan tutur tidak dapat berjalan dengan lancar, sehingga terjadi pelanggaran prinsip kerja sama.

Pelanggaran prinsip kerja banyak ditemukan di berbagai media, seperti media tulis dan media audio visual. Media tulis dapat berupa majalah, koran, dan lain-lain. Media visual yaitu alat yang dapat didengar dan dilihat, contohnya seperti televisi.

Tayangan yang disiarkan di televisi yang mampu menarik perhatian publik salah satunya yaitu acara talk show Rosi. Rosi merupakan suatu program acara yang ditayangkan pada salah satu stasiun televisi swasta berita nasional di Indonesia, yaitu Kompas TV. Acara Rosi disiarkan pada setiap hari Kamis pada pukul 19.30 WIB sampai dengan pukul 21.00 WIB di Kompas TV dan dibawakan oleh seorang pewawancara yaitu Rosi Silalahi. Program ini selalu menghadirkan tema yang sesuai dengan isu-isu yang terbaru, sehingga setiap episode temanya selalu berbeda. Isi dari topik dalam acara talk show Rosi tersebut yaitu ada membahas bidang politik, sosial, ekonomi, dan budaya. Selain itu, tayangan ini juga menampilkan suatu perdebatan, suka cita, hingga haru biru. Acara Rosi dibawakan oleh salah seorang pewawancara, yaitu Rosianna Magdalena Silalahi atau lebih dikenal dengan Rosianna Silalahi. Beliau juga akrab dipanggil dengan nama Rosi.

Pertanyaan yang diajukan Rosi kepada narasumber terkadang memicu narasumbernya untuk melakukan pelanggaran prinsip kerja sama, sehingga dari tuturan tersebut dapat memancing argumen dari narasumber, sehingga tercipta tanggapan dan pembahasan yang panjang dari tuturan itu. Hal tersebut disebabkan lawan tutur mempunyai maksud atau tujuan tertentu dari pelanggaran tersebut, sehingga hal itu dapat menyebabkan meluasnya topik pembahasan serta komunikasi tidak dapat berjalan dengan baik dan tidak tertata.

Rohmadi (2010, hal. 126) menjelaskan seorang penutur atau penulis tidak selamanya mematuhi prinsip-prinsip kerja sama dan kesopanan dalam penggunaan bahasa. Adakalanya seorang penulis atau penutur sengaja melakukan 
penyimpangan-penyimpangan terhadap prinsip-prinsip penggunaan bahasa tersebut. Penyimpangan-penyimpangan terhadap prinsip-prinsip penggunaan bahasa menunjukkan adanya maksudmaksud tertentu yang ingin dicapai penulis atau penutur. Jika penutur tidak mempunyai maksud atau tujuan tertentu dari penyimpangan tersebut, maka komunikasi akan mengalami hambatan. Penyimpangan ini sengaja dilakukan dengan tujuan untuk mengutarakan maksudnya secara halus.

Salah satu penelitian relevan yang berkaitan dengan penyimpangan prinsip kerja sama pernah dilakukan oleh Retnowaty (2013) dengan judul "The Awareness and Realization of Grice's Cooperative Principles in the Conversations among Non-Native English Speakers". Hasil penelitiannya adalah most participants appeared to observe the maxim of relation. The realization of nonobservance of Grice's cooperative principle was mostly shown in flouting the maxim of quantity that they gave more or less information than it was needed yang artinya kebanyakan partisipan mematuhi maksim relevansi dan realisasi pelanggaran maksim kerja sama paling terlihat pada pelanggaran maksim kuantitas. Penelitian tersebut memiliki objek pembicara bukan native English speaker dan penelitian ini memiliki objek talkshow Rosi.

Pembahasan dalam acara Rosi dengan tema yang disajikan selalu berbeda dalam setiap episodenya serta narasumber yang berbeda pula, sehingga cara narasumber dalam menyampaikan argumennya juga berbeda-beda. Gaya bahasa narasumber tersebut juga berbeda sesuai dengan latar belakang pendidikan dan asal daerah.

Berdasarkan latar belakang di atas, maka tujuan penelitian ini yaitu mendeskripsikan bentuk-bentuk pelanggaran prinsip kerja sama dalam percakapan pada acara Rosi di Kompas TV.

\section{METODE PENELITIAN}

Pendekatan yang digunakan dalam penelitian adalah pendekatan pragmatik dengan data deskriptif, yaitu dengan memaparkan data, menganalisis data, mengklasifikasikan data yang diperoleh, dan mendeskripsikan data. Tahapantahapan tersebut yaitu dengan mengumpulkan data dengan cara menyimak dan mencatat, analisis data, dan penyajian data. Data yang dideskripsikan berasal dari rekaman video acara Rosi di Kompas TV pada bulan Juni 2018. Jenis penelitian yang digunakan dalam penelitian ini mengacu pada penelitian deskriptif, yaitu penelitian yang menghasilkan data berupa kata-kata tertulis atau lisan dari orang-orang dan perilaku yang dapat diamati.

Data dalam penelitian ini berupa dokumen transkip berupa percakapan antara penutur dan lawan tutur dalam talk show Rosi di Kompas TV yang difokuskan pada bulan Juni 2018 yang melanggar maksim kuantitas, maksim kualitas, maksim relevansi, dan maksim cara. Sumber data penelitian ini berupa data unduhan dari youtube yaitu talk show Rosi bulan Juni 2018 yang berjumlah 3 video.

Pengumpulan data dalam penelitian ini menggunakan metode simak dan teknik catat, setelah itu menandai setiap tuturan yang mengandung pelanggaran prinsip kerja sama, kemudian dikaitkan dengan konteks, dan dianalisis berdasarkan bentuk pelanggaran kerja sama menurut Grice dan menjelaskan maksud dari pelanggaran tersebut.

\section{HASIL DAN PEMBAHASAN}

Berdasarkan penelitian yang telah dilakukan, maka ditemukan hasil berupa deskripsi pelanggaran prinsip kerja sama dalam talk show Rosi di Kompas TV pada bulan Juni 2018. Pelanggaran prinsip kerja sama pada satu maksim yang ditemukan berupa maksim kuantitas, maksim kualitas, maksim relevansi, dan maksim pelaksanaan/cara. Pelanggaran prinsip kerja sama lebih dari satu maksim yang 
ditemukan berupa maksim kuantitas-cara, maksim kuantitas-kualitas, maksim kualitas-cara, dan maksim relevansi-cara. Hasil pendeskripsian tuturan yang melanggar prinsip kerja sama yang ditemukan dalam talk show Rosi di Kompas $T V$ dapat dilihat dalam tabel frekuensi pelanggaran prinsip kerja sama berikut.

Tabel 1

Frekuensi Pelanggaran Prinsip Kerja Sama Talk Show Rosi di Kompas TV

\begin{tabular}{|c|l|l|c|}
\hline No. & $\begin{array}{l}\text { Pelanggar } \\
\text { an } \\
\text { Maksim }\end{array}$ & \multicolumn{1}{|c|}{$\begin{array}{c}\text { Jenis } \\
\text { Maksim }\end{array}$} & Frekuensi \\
\hline \multirow{4}{*}{ 1. } & \multirow{3}{*}{$\begin{array}{l}\text { Satu } \\
\text { Maksim }\end{array}$} & Kuantitas & 31 \\
\cline { 3 - 4 } 2. & Kualitas & 2 \\
\cline { 3 - 4 } & Relevansi & 4 \\
\cline { 3 - 4 } & Lebih dari & Cara \\
Maksim & $\begin{array}{l}\text { Kuantitas- } \\
\text { Cara }\end{array}$ & 2 \\
\cline { 3 - 4 } & $\begin{array}{l}\text { Kuantitas- } \\
\text { Kualitas }\end{array}$ & 2 \\
\cline { 3 - 4 } & $\begin{array}{l}\text { Kualitas- } \\
\text { Cara }\end{array}$ & 2 \\
\cline { 3 - 4 } & $\begin{array}{l}\text { Relevansi- } \\
\text { Cara }\end{array}$ & 11 \\
\hline \multicolumn{2}{|c|}{ Jumlah } & 55 \\
\hline
\end{tabular}

Tabel 1 telah menunjukkan bahwa terjadi pelanggaran prinsip kerja sama dengan jumlah 55 data. Pelanggaran yang terjadi pada satu maksim yaitu terdapat dalam maksim kuantitas dengan terjadi pelanggaran yaitu sebanyak 31 data. Hal tersebut dikarenakan lawan tutur dalam menyampaikan informasi secara berlebihan dan tidak sesuai dengan yang dibutuhkan penutur. Hasil ini sejalan dengan penelitian relevan milik Retnowaty (2013).

Pelanggaran yang terjadi pada maksim kualitas terdapat 2 data hal itu disebabkan karena lawan tutur dalam memberikan informasi kurang meyakinkan atau tidak disertakan buktibukti untuk menguatkan opininya. Pelanggaran yang terjadi pada maksim relevansi terdapat 4 data, hal itu disebabkan karena lawan tutur dalam memberikan jawaban tidak sesuai dengan apa yang ditanyakan dan tidak sesuai dengan konteks. Pelanggaran yang terjadi pada maksim cara terdapat 11 data, hal itu disebabkan karena lawan tutur dalam menyampaikan jawaban atau pendapatnya terlalu berbelit-belit tidak langsung pada intinya serta terkadang juga terdapat ambiguitas.

Pelanggaran yang terjadi lebih dari satu maksim yaitu pelanggaran maksim kuantitas dan cara terdapat 2 data, hal itu dikarenakan lawan tutur dalam memberikan informasi secara berlebihan dan berbelit-belit atau bertele-tele dan panjang lebar dalam memberikan informasi. Pelanggaran yang terjadi pada maksim kuantitas dan kualitas terdapat 2 data, hal itu dikarenakan lawan tutur dalam menjawab yaitu melebihi informasi dari yang dibutuhkan serta tidak memberikan bukti atas pernyataannya, sehingga kurang meyakinkan. Pelanggaran pada maksim kualitas dan cara terdapat 2 data, hal itu dikarenakan lawan tutur tidak menyertakan bukti yang meyakinkan dan terlalu bertele-tele serta panjang lebar dalam menyampaikan informasi. Pada pelanggaran maksim relevansi dan maksim cara terdapat 1 data, hal itu disebabkan karena lawan tutur dalam memberikan jawaban tidak relevan dengan pertanyaan dan berbelit-belit dalam menyampaikan informasi.

Tuturan-tuturan yang terdapat di bawah ini merupakan pelanggaranpelanggaran satu maksim yang terjadi di dalam talk show Rosi di Kompas TV pada bulan Juni 2018.

\section{[PMKN/5-07]}

Rosi :

"Pak, sepakat nggak kalau pemerintah dan DPR tindak korupsi ini adalah tindak kejahatan yang luar biasa?" Prof. Muladi :

"istilah luar biasa itu tidak ada, tetapi kejatuhan berat.... yang masuk di dalam tindak pidana khusus itu terorisme, pencucian uang, korupsi, dan pelanggaran berat HAM dan sebagainya.'

(7 Juni 2018) 
Tuturan pada data [PMKN/5-07] merupakan dialog percakapan antara pembawa acara selaku penutur dan narasumber selaku lawan tutur. Rosi menghadirkan narasumber Prof. Muladi selaku koordinator tim ahli R-KUHP dalam tema ancaman baru pelemahan KPK. Konteks yang melatarbelakangi dialog tersebut yaitu Rosi membacakan kutipan kiriman surat KPK kepada Presiden yang berisi sesungguhnya KPK keberatan dengan dicantumkan rumusan tindak pidana korupsi dalam RUU KUHP yang berlalu selama 2 tahun, KPK berpendapat pencantuman tersebut yaitu kasus korupsi di KUHP akan menghilangkan status tindak pidana khusus yang bersifat luar biasa.

Proses komunikasi pada tuturan di atas telah melanggar maksim kuantitas, karena lawan tutur yaitu Prof. Muladi telah memberikan informasi lebih dari yang dibutuhkan oleh penutur. Hal tersebut dikarenakan penutur belum membutuhkan informasi perihal apa saja yang terdapat di dalam tindak pidana khusus. Hal tersebut dapat dilihat pada kalimat "Yang masuk di dalam tindak pidana khusus itu terorisme, pencucian uang, korupsi, dan pelanggaran berat HAM dan sebagainya" sebenarnya penutur hanya menginginkan jawaban dari narasumber sepakat atau tidak mengenai tindak korupsi merupakan kejahatan yang luar biasa, tetapi narasumber berlebihan dalam memberikan informasi yaitu dengan menjelaskan contoh-contoh pidana yang terdapat di dalam tindak pidana khusus, hal tersebut dimaksudkan untuk menguatkan pendapatnya mengenai ketidaksepakatannya mengenai tindak korupsi yang dikatakan sebagai tindak kejahatan yang luar biasa, melainkan korupsi merupakan bagian dari tindak pidana khusus.

\section{[PMKL/13-07]}

\section{Rosi :}

"bung Saor apakah Anda sebagai praktisi hukum akan melihat ini sebagai kerancuan?"

\section{Saor Siagian :}

"saya komentar dulu saudara Arsul mengatakan kalau ada dua ahli hukum, kemudian bisa pendapatnya lebih dari dua. Dia juga punya statement soal suuzan, ia tidak konsisten soal itu. Menurut saya adalah sifat ambigu dari saudara Arsul mestinya cara pandang dia itu harus konsisten dengan mengatakan masyarakat sipil atau siapa pun dengan argumentasi dengan pendapatnya tidak mengatakan suuzan."

(7 Juni 2018)

Tuturan pada data [PMKL/13-07] peristiwa tutur yang terjadi adalah pembawa acara sebagai penutur dan narasumber sebagai lawan tutur. Narasumber yang dihadirkan adalah Saor Siagian yang merupakan seorang praktisi hukum. Konteks yang melatarbelakangi tuturan tersebut yaitu menanggapi opini Arsul Sani yang mengatakan masyarakat sipil telah bersuuzan pada undang-undang tipikor yang akan dimasukkan ke dalam KUHP, serta pula menanggapi ucapan Arsul Sani yang mengatakan bahwa dua lawyer dapat menghasilkan tiga pendapat.

Tuturan yang disampaikan oleh narasumber jelas melanggar maksim kualitas. Hal itu disebabkan narasumber tidak memberikan bukti yang kuat dengan pernyataan tersebut. Hal itu dapat dilihat pada kalimat "menurut saya adalah sifat ambigu dari saudara Arsul mestinya cara pandang dia itu harus konsisten dengan mengatakan masyarakat sipil atau siapa pun dengan argumentasi dengan pendapatnya tidak mengatakan suuzan" terlihat jelas bahwa narasumber sangat tidak terima dengan pernyataan Arsul Sani yang mengatakan masyarakat sipil memiliki sifat suuzan, seharusnya narasumber dalam memberikan opini mengenai Arsul Sani yang memiliki sifat ambigu disertakan bukti atau contoh yang menguatkan opininya tersebut, agar cara pandang dari Arsul Sani dapat konsisten sesuai dengan ucapannya yang diharapkan dari narasumber yaitu tidak mudah 
mengatakan suuzan kepada masyarakat sipil atau siapa pun.

\section{[PMRL/18-14]}

\section{Sujiwo Tejo :}

"Tapi sebelumnya aku mau tanya dulu ke pemirsa yang hadir di sini. Jujur ya jujur ini jujur, baju ku sama bajunya Rosi bagusan mana?"

\section{Penonton :}

\section{Rosi :}

"Mbak Rosi..."

"Ayo dong bagusan mana bajuku atau Mas Tejo ?"

Penonton :

"Mas Tejo..."

\section{Sujiwo Tejo :}

"tapi yang penting yang mendukung $a k u$, maupun mendukung Rosi yang penting jangan berantem, kita sama-sama satu bangsa."

(14 Juni 2018)

Tuturan pada data [PMRL/18-14] merupakan dialog yang terjadi antara pembawa acara, penonton, dan narasumber. Rosi menghadirkan narasumber Sujiwo Tejo selaku budayawan. Konteks yang melatarbelakangi tuturan tersebut yaitu pembawa acara dan narasumber menanyakan kepada penonton baju yang paling bagus yang mana Rosi memakai baju warna ungu dan Sujiwo memakai baju warna Hijau.

Pada pernyataan yang dinyatakan narasumber dalam menanggapi jawaban penonton terlihat jelas melanggar maksim relevansi. Bila dikaitkan dengan konteks, pernyataan yang diungkapkan narasumber tidak ada kaitannya dengan yang sedang dibicarakan, karena pada saat itu sedang membahas baju. Hal tersebut dapat terlihat pada kalimat "tapi yang penting yang mendukung aku, maupun mendukung Rosi yang penting jangan berantem, kita samasama satu bangsa" yang mana narasumber ingin menyampaikan sesuatu. Narasumber ingin mengungkapkan suatu pesan yaitu apapun yang disukai atau apapun yang dipilih, kita tetap satu bangsa yaitu Indonesia yang mana kita harus tetap bersatu apapun pilihan kita jangan sampai terpecah belah atau berkelahi karena berbeda pilihan.

\section{[PMCR/42-28]}

\section{Rosi :}

"jadi perasaan hati anda sebenarnya sama dengan mayoritas banyak orang yang wah kaget juga?

\section{Yunarto Wijaya :}

"sebenarnya terjelaskan, tapi kalau pertanyaannya pada saat quick count dilakukan ada pertanyaan yang muncul, itu iya."

(28 Juni 2018)

Data [PMCR/42-28] merupakan dialog yang terjadi antara pembawa acara sebagai penutur dan lawan tutur dalam dialog tersebut yaitu narasumber. Narasumber yang dihadirkan pembawa acara merupakan Direktur Eksekutif Charta Politika yaitu Yunarto Wijaya. Charta Politika merupakan lembaga konsultan politik yang melakukan pendataan dan pemetaan pada analisis politik. Konteks yang melatarbelakangi tuturan tersebut yaitu menanggapi perihal rasa terkejut bagi pasangan nomor tiga Jawa Barat yang memperlihatkan rata-rata dari lembaga survei dengan selisih yang agak jauh.

Tuturan dari lawan tutur jelas melanggar maksim cara, karena memberikan jawaban yang berbelit-belit dan tidak memberikan pernyataan secara langsung, sehingga dari tuturan tersebut sulit dipahami maksudnya. Hal tersebut dapat dilihat pada kutipan "sebenarnya terjelaskan, tapi kalau pertanyaannya pada saat quick count dilakukan ada pertanyaan yang muncul, itu iya." Bila dikaitkan dengan konteks lawan tutur sebenarnya ingin menjawab bahwa ia terkejut dengan adanya selisih yang agak jauh yang dilakukan lembaga survei dengan hasil yang keluar pada saat quick count, tetapi lawan tutur justru memberi 
alasan jika hal itu dipertanyakan pada saat quick count ia akan menjawab terkejut. Jadi lawan tutur memberikan pernyataan yang berbelit-belit untuk menjawab bahwa sebenarnya ia terkejut dengan hasil survei yang dilakukan lembaga survei dengan hasil quick count atau hitung cepat.

Tuturan-tuturan yang terdapat di bawah ini merupakan pelanggaranpelanggaran lebih dari satu maksim yang terjadi di dalam talk show Rosi di Kompas TV pada bulan Juni 2018.

\section{[PMKN.PMCR/8-07]}

Rosi :

"itu yang membuat kerancuan, kalau memang tetap berlaku kenapa tidak memakai undang-undang tindak pidana korupsi ? Bagaimana bung Saor ?"

\section{Saor Siagian :}

"saya mulai dulu konstruksi pembentukan undang-undang Mbak Rosi artinya bahwa satu produk undangundang kan produk daripada eksekutif dan legislatif. Nah, artinya bahwa ketika undang-undang itu dibuat, kan bukan untuk kepentingan dua lembaga ini ? Tetapi adalah usernya, tapi jauh lebih penting itu bagaimana undang-undang ini bermanfaat kepada masyarakat. Kita langsung kepada undang-undang Tipikor, ini dari awal kalau konsen dari Pak Muladi adalah kodifikasi untuk penyederhanaan atau untuk konsepsi, mestinya seluruh undang-undang yang khusus supaya jangan tanggung-tanggung harus dimasukin. Salah satu unsur dari pada undang-undang Tipikor ini adalah KPK, sampai sejauh ini kami tidak butuh. Sudah cukup dengan undang-undang ini. Pertanyaan saya adalah mengapa pemerintah dan DPR itu ngotot? Padahal undang-undang ini dibuat untuk kepentingan kepada rakyat sebagai pemilik daulat."

(7 Juni 2018)

Pada data [PMKN.PMCR/8-07] peristiwa tutur yang terjadi adalah pembawa acara sebagai penutur dan narasumber sebagai lawan tutur. Narasumber yang didatangkan Rosi yaitu Saor Siagian. Saor Siagian merupakan seorang praktisi hukum. Konteks yang melatarbelakangi tuturan tersebut yaitu KPK tidak menginginkan kasus tindak pidana korupsi masuk kedalam KUHP, karena akan menjadi ancaman bagi KPK dan menanggapi pernyataan Prof. Muladi yang menyatakan kewenangan KPK terhadap kasus korupsi seperti yang tertera dalam undang-undang nomor 3 tahun 2002 tetap berlaku.

Tuturan pada data di atas jelas melanggar maksim kuantitas dan maksim cara. Pada maksim kuantitas terjadi pelanggaran karena memberikan informasi secara berlebihan. Hal tersebut dapat dilihat pada kalimat "konstruksi pembentukan undang-undang artinya bahwa satu produk undang-undang kan produk daripada eksekutif dan legislatif. Undang-undang itu dibuat, kan bukan untuk kepentingan dua lembaga ini? Tetapi adalah usernya". Seharusnya narasumber yaitu Saor Siagian cukup dengan menjawab pertanyaan dari Rosi mengenai pernyataan Prof. Muladi tentang undang-undang nomor 3 tahun 2002 yang tetap berlaku. Saor Siagian justru sebelum menanggapi pernyataan dari Prof. Muladi yaitu Saor memberikan informasi tambahan mengenai bagaimana pembentukan undang-undang itu merupakan produk dari eksekutif dan legislatif yang mana undang-undang itu bermanfaat untuk masyarakat, tetapi bukan untuk kedua lembaga.

Selain itu juga terdapat maksim cara di dalam data tersebut, yaitu lawan tutur untuk menyampaikan maksudnya terlalu berbelit dan tidak langsung kepada inti pembicaraannya. Hal itu dapat dilihat pada kalimat "dari awal kalau konsen dari Pak Muladi adalah kodifikasi untuk penyederhanaan atau untuk konsepsi, mestinya seluruh undang-undang yang khusus supaya jangan tanggung-tanggung harus dimasukin. Salah satu unsur dari pada undang-undang Tipikor ini adalah 
KPK, sampai sejauh ini kami tidak butuh. Sudah cukup dengan undang-undang ini. Pertanyaan saya adalah mengapa pemerintah dan DPR itu ngotot? Padahal undang-undang ini dibuat untuk kepentingan kepada rakyat sebagai pemilik daulat." Dalam pernyataan narasumber di atas bila dikaitkan dengan konteks yang menanggapi pernyataan Prof.Muladi mengenai kewenangan KPK masih berlaku seperti yang tertera dalam undang-undang nomor 3 tahun 2002 yaitu lawan tutur menginginkan seluruh undangundang dikodifikasi bukan hanya tindak pidana korupsi saja, karena kasus tindak pidana korupsi sudah menjadi konsen KPK yang menjadi kewenangan dan tugasnya, jadi tidak perlu lagi dimasukkan lagi ke dalam KUHP. Selain itu juga lawan tutur mengulang lagi pernyataannya bahwa undang-undang tersebut dipergunakan kepada masyarakat selaku pemilik daulat yang lebih memiliki hak untuk keadilan.

\section{[PMKN.PMKL/4-07]}

\section{Rosi :}

"kalau dari sisi KPK bagaimana?"

\section{Emerson Yuntho :}

"kalau dari sisi KPK begini di pasal 1 undang-undang KPK jelas menyebutkan bahwa dalam konteks kewenangan penindakan KPK merujuk pada UndangUndang Tipikor. Undang-undang Tipikor bukan KUHP, kalau undang-undang KUHP diberlakukan artinya KPK tidak punya kewenangan soal itu. Tadi disebutkan oleh Pak Muladi pasal 729 soal RUU KUHP jangan khawatir, ini kaya kita dikasih pepesan kosong seolah-olah menyederhanakan persoalan, tenang aja pemerintah tidak akan mungkin melakukan upaya pelemahan. Perlu diingat Mbak Rosi bahwa di DPR itu sebagian teman-temannya Pak Arsul itu tidak terlalu suka dengan KPK, pasal 729 ini sangat mungkin untuk di drop, kalau di drop sudah hilang kewenangan KPK."

(7 Juni 2018)
Pada data [PMKN.PMKL/4-07] peristiwa tutur yang terjadi yaitu pembawa acara sebagai penutur dan narasumber sebagai lawan tutur. Rosi menghadirkan narasumber yaitu Emerson Yuntho. Emerson Yuntho merupakan seorang koordinator divisi monitoring hukum dan peradilan ICW. Konteks yang melatarbelakangi tuturan tersebut yaitu menanggapi perihal undang-undang tindak pidana korupsi yang akan dimasukkan ke dalam KUHP yang tentunya akan mengalami pengurangan-pengurangan hukuman.

Data tersebut melanggar maksim kuantitas, karena menambahkan informasi lebih dari yang dibutuhkan oleh penutur atau pembawa acara. Bila dikaitkan dengan konteks penutur hanya menginginkan jawaban dari sisi KPK untuk menanggapi pernyataan dari Prof. Muladi yang mau memasukkan tindak pidana korupsi ke dalam KUHP. Agar lebih jelas dapat dilihat pada kalimat "undang-undang Tipikor bukan KUHP, kalau undang-undang KUHP diberlakukan artinya KPK tidak punya kewenangan soal itu. Tadi disebutkan oleh Pak Muladi pasal 729 soal RUU KUHP jangan khawatir, ini kaya kita dikasih pepesan kosong seolah-olah menyederhanakan persoalan, pasal 729 ini sangat mungkin untuk di drop, kalau di drop sudah hilang kewenangan KPK”. Lawan tutur justru menambahkan informasi bahwa undang-undang Tipikor (tindak pidana korupsi) bukan merupakan KUHP, selain itu juga lawan tutur juga membahas ucapan dari Prof. Muladi tentang pasal 729 yang mengatakan bahwa KPK tidak perlu khawatir dengan adanya undang-undang tindak pidana korupsi ini dimasukkan ke dalam KUHP yang menurut lawan tutur terlalu menyepelekan persoalan ini dan dari pernyataanpernyataan itu terlihat jelas bahwa sebenarnya lawan tutur sangat khawatir bahwa kewenangan KPK akan hilang jika pasal 729 ini dihilangkan yang berarti KPK tidak memiliki kewenangan untuk 
melakukan tugasnya untuk memberantas kasus korupsi.

Pelanggaran maksim kualitas juga terdapat dalam data itu, karena lawan tutur tidak menyertakan bukti dari yang dibicarakan. Hal tersebut dapat dilihat pada kalimat "bahwa di DPR itu sebagian teman-temannya Pak Arsul itu tidak terlalu suka dengan KPK”. Pada pernyataan itu lawan tutur atau narasumber tidak memberikan bukti-bukti jika memang sebagian anggota DPR itu tidak suka dengan KPK, sehingga dari pernyataannya itu telah melanggar maksim kualitas, karena berbicara hanya berdasarkan dengan pendapatnya saja.

\section{[PMKL.PMCR/2-07]}

\section{Rosi :}

"Prof saya mau nanya, KPK itu masih bisa OTT lagi gak ?"

\section{Prof. Muladi :}

"saya kira gak ada masalah, KPK OTT kan hukum masalah pidana saat ini itu kita bicara hukum pidana materil, kalau OTT saya kira tidak ada masalah. Tidak ada pelemahan KPK itu tidak ada, salah besar itu kalau RUU KUHP itu bisa melemahkan KPK karena di dalam undang-undang itu saya katakan kalau membaca RUU itu harus utuh tidak sepotong-sepotong itu yang terjadi sekarang itu sepotong-sepotong."

(7 Juni 2018)

Pada data [PMKL.PMCR/2-07] Rosi menghadirkan narasumber yaitu Prof. Muladi. Prof. Muladi merupakan seorang koordinator tim ahli R-KUHP. Konteks yang melatarbelakangi yaitu menanggapi perihal undang-undang tindak pidana korupsi yang masuk dalam rancangan KUHP yang dinilai dapat melemahkan KPK.

Tuturan di atas lawan tutur melanggar 2 maksim sekaligus yaitu maksim kualitas dan maksim cara, karena lawan tutur dalam menyampaikan jawabannya tidak memberi jawaban yang berdasarkan dengan bukti-bukti yang ada dan terlalu berbelit-belit serta ambigu tidak langsung kepada inti jawaban yang sedang dipertanyakan. Hal tersebut dapat dilihat pada kalimat lawan tutur yang menjawab dengan "saya kira" dengan berulang kali tanpa memberikan fakta atau bukti bahwa KPK masih bisa melakukan OTT (Operasi Tangkap Tangan) atau tidak, lawan tutur justru menjawab dengan "saya kira gak ada masalah, KPK OTT kan hukum masalah pidana saat ini itu kita bicara hukum pidana materil, kalau OTT saya kira tidak ada masalah" lawan tutur masih mengira-mengira perihal OTT yang dilakukan KPK masih bisa dilakukan atau tidak, tanpa ada kejelasan yang belum pasti kebenarannya. Selain itu juga lawan tutur melanggar maksim cara yang mana dari awal pernyataannya terlalu memutarmemutar omongannya, sehingga tidak mendapatkan informasi yang dibutuhkan, justru lawan tutur memberikan pernyataan bahwa tidak ada pelemahan yang akan terjadi pada KPK dan lawan tutur menginginkan bahwa kalau membaca RUU itu harus seutuhnya jangan setengahsetengah yang berdampak mendapatkan informasi yang tidak akurat.

\section{[PMRL.PMCR/9-07]}

Rosi :

"pertanyaan paling dasar, memang DPR ini selalu mau ganggu KPK ya ?"

\section{Arsul Sani:}

"saya yang senang kalau melihat mas Eson, sesungguhnya dia itu politisi. Biasanya kalau politisi itu melihat sesuatu dengan suuzan dulu sampai terbukti husnudzan, tapi kali ini teman-teman masyarakat sipil yang bertindak jadi politisi melihat undang-undang ini suuzan dulu yang dikedepankan. Persoalan yang kemudian adalah prasangka buruk itu dikedepankan tanpa membaca secara keseluruhan pasal-pasal yang kami bahas di dalam RUU KUHP ini. Pasal 205 yang merupakan aturan penutup dari buku 1 KUHP itu mengatakan ketentuan dalam bab 1 sama bab 5 berarti tentang jenis pidana termasuk pidana tambahannya, itu 
tetap berlaku untuk kejahatan yang diatur ini kecuali ditentukan lain menurut undang-undang."

(28 Juni 2018)

Data [PMRL.PMCR/9-07] peristiwa tutur yang terjadi adalah pembawa acara sebagai penutur dan narasumber sebagai lawan tutur. Narasumber yang dihadirkan Rosi adalah Arsul Sani selaku anggota Panja RUU KUHP/F-PPP. Konteks yang melatarbelakangi tuturan tersebut adalah menanggapi pernyataan Saor Siagian tentang undang-undang tindak pidana korupsi yang tidak perlu di masukan ke dalam KUHP, karena undang-undang Tipikor sudah ada yang menangani yaitu KPK.

Tuturan yang terjadi lawan tutur jelas melanggar maksim relevansi dan maksim cara. Maksim relevansi yaitu lawan tutur tidak memberikan kontribusi jawaban yang sesuai, bila dikaitkan dengan konteks juga tidak ada kaitannya dengan jawaban yang telah dikontribusikan. Hal tersebut dapat dilihat pada kalimat "saya yang senang kalau melihat mas Eson, sesungguhnya dia itu politisi. Biasanya kalau politisi itu melihat sesuatu dengan suuzan dulu sampai terbukti husnuzan, tapi kali ini teman-teman masyarakat sipil yang bertindak jadi politisi melihat undang-undang ini suuzan dulu yang dikedepankan". Pada jawaban yang di kontribusikan lawan tutur justru memberikan pernyataan yang di luar dari pertanyaan yang diberikan. Lawan tutur justru memberikan jawaban yang sedikit menyindir masyarakat sipil yang menanggapi masalah tindak pidana korupsi ke dalam KUHP ini dengan prasangka buruk tanpa mengetahui tujuan yang sebenarnya.

Selain itu juga lawan tutur memberikan pernyataan yang terlalu panjang lebar dan bertele-tele yang mana lawan tutur dalam menyampaikan maksudnya seperti yang ada dalam kalimat "pasal 205 yang merupakan aturan penutup dari buku 1 KUHP itu mengatakan ketentuan dalam bab 1 sama bab 5 berarti tentang jenis pidana termasuk pidana tambahannya, itu tetap berlaku untuk kejahatan yang diatur ini kecuali ditentukan lain menurut undangundang" justru terlalu panjang lebar dan bertele-tele dalam menyampaikan informasi yaitu dengan mengatakan suuzan atau prasangka buruk terlebih dahulu untuk menjelaskan maksudnya mengenai tentang jenis pidana dan pidana tambahan yang terdapat di dalam KUHP.

\section{KESIMPULAN}

Berdasarkan hasil penelitian dan pembahasan, yaitu pelanggaran yang paling dominan sering muncul yaitu pelanggaran maksim kuantitas, hal itu disebabkan narasumber memberikan informasi yang berlebihan dan tidak sesuai yang dibutuhkan penutur. Hal itu sengaja dilakukan untuk memperjelas dari pernyataan yang telah diungkapkan. Sedangkan pelanggaran yang paling jarang muncul yaitu pada pelanggaran maksim relevansi-cara, karena peserta komunikasi memberikan informasi tidak menjawab sesuai dengan pertanyaan dan konteks serta bertele-tele dan panjang lebar dalam menyampaikan informasi.

\section{DAFTAR PUSTAKA}

Djatmika. (2016). Mengenal Pragmatik Yuk!? Yogyakarta: Pustaka Pelajar.

Nadar, F. (2009). Pragmatik dan Penelitian Pragmatik. Yogyakarta: Graha Ilmu.

Retnowaty, R. (2013). The Awareness and Realization of Grice'S Cooperative Principles in the Conversations Among Non-Native English Speakers. English Education Journal (Program Pascasarjana Universitas Negeri Semarang), 3(2), 68-77.

Rohmadi, M. (2010). Pragmatik Teori dan Analisis. Surakarta: Yuma Pustaka. 